\title{
Sobre a maneira neopirrônica de agir e pensar
}

\author{
Plínio Junqueira Smith \\ Unifesp / CNPq
}

\section{RESUMO}

O texto busca apresentar a atualização das atitudes céticas, como a suspensão do juízo, e sua incidência no campo da atitude nas ciências e na vida. Com o intuito de descrever em linhas gerais como é, ou pode ser, uma vida neopirrônica, para que o leitor julgue isso por si mesmo.

\section{PALAVRAS-CHAVE}

Ceticismo; Neopirronismo; Atitude cética.

\begin{abstract}
The text seeks to present the update of skeptical attitudes, such as the suspension of judgment, and its impact on the field of attitude in the sciences and in life. In order to describe in general terms what a neo-pirronic life is, or can be, so that the reader can judge it for himself.
\end{abstract}

\section{KEY WORDS}

Skepticism; Neopyrronism; Skeptical Attitude. 
As coisas se apresentam, na vida cotidiana, das maneiras mais variadas possíveis: uma nuvem branca, quando o sol se póe, torna-se rosada; o mar azul, se essa mesma nuvem projeta sua sombra, torna-se acinzentado; o ouro puro é amarelo, mas, se impuro, é branco ${ }^{1}$. Em função de nosso estado, percebemos uma mesma coisa de diferentes maneiras: uma pessoa doente sente um gosto amargo ao tomar vinho, enquanto outro sente um gosto doce; uma pessoa sóbria vê o muro parado, mas o bêbado vê o muro se mexer. Além disso, os seres humanos vivem de maneiras muito diferentes nas diferentes sociedades, o que é permitido aqui é proibido ali, e suas vidas estão em constante transformação, pois novos costumes substituem os velhos. Embora em um grau certamente inferior, as ciências não parecem estar isentas de divergências. Também nelas, inclusive nas matemáticas e na lógica, há muitos desacordos. Um pouco de estudo de qualquer uma delas mostra, náo somente que ao longo de suas histórias as divergências sempre estiveram presentes, mas também que não desapareceram nos dias atuais. Conquanto exista um amplo consenso sobre o aquecimento global, há ainda discordâncias sobre a sua causa. Tampouco é óbvio o modo como se poderia conciliar a mecânica quântica com a relatividade, já que aparentemente não se pode aceitar as duas ao mesmo tempo. Esses desacordos se fazem ainda mais evidentes em outras áreas do saber como a psicologia, a história, a antropologia e a economia. $\mathrm{Na}$ filosofia, em particular, multiplicam-se de tal maneira que não há um só tema filosófico que não contenha inúmeros deles.

O que pensar desses desacordos que se manifestam na vida cotidiana, nas ciências e na filosofia? As reaçóes humanas ao desacordo são as mais diversas possíveis: uns se tornam ainda mais inflexíveis em suas posições; outros, mais conciliadores, diminuem a convicção que tinham (Frances, 20I4, parte II; Christensen e Lackey, 20I3, parte I); outros ainda podem mudar de lado e passar a acreditar naquilo que antes rejeitavam. Qual é, entretanto, a atitude mais ponderada a se tomar diante de um desacordo? Haveria uma atitude mais racional? Uma coisa é certa: porque não se podem aceitar opinióes conflitantes entre si, temos de decidir entre o que é verdadeiro e o que é falso num desacordo. Quando se deseja conhecer a verdade, um impulso natural em nós, sentimo-nos perturbados pelo desacordo, pois não temos

1 Eu gostaria de agradecer a Danilo Marcondes de Souza Filho, Roberto Bolzani Filho, Roberto Horácio de Sá Pereira e Waldomiro José da Silva Filho por seus comentários a uma versão prévia deste artigo, que me ajudaram muito a chegar a esta versão publicada. O leitor logo perceberá que a organizaçáo de minhas ideias segue bem de perto a organizaçáo das ideias de Porchat em seu texto seminal "Sobre o que aparece", assim como perceberá que as ideias aqui apresentadas se apoiam em grande parte nas ideias de Porchat, defendidas não somente nesse texto, como também em alguns outros de seus textos. Tal é a dependência de meu artigo que é impossível citar os textos que tenho em mente, porque, nesse caso, deveria haver referências em quase todas as frases. Endossando, adaptando ou modificando suas ideias, pretendo homenagear aquele que foi o meu maior mestre. 
a desejada verdade. Daí, talvez, a razão pela qual muitos se tornam rígidos em suas posturas, recusando-se a enfrentar o desafio lançado pelo desacordo. Para outras pessoas, no entanto, essa ansiedade incita sua curiosidade e leva-os a uma investigação da verdade (Sexto PH, I.I2). Parece, entâo, que uma primeira reaçáo racional é reconhecer a própria ignorância e, sem aceitar nenhuma das opinióes conflitantes, pôr-se a examinar cuidadosamente a questão (PH, 2.II; Friedman, 20I7).

$\mathrm{Na}$ vida cotidiana, amiúde podem-se resolver desacordos. Uma pessoa pode achar que esqueceu um livro no metrô e um amigo achar que está na sua casa; ora, se ela descobre o livro debaixo do sofá no dia seguinte, isso mostra que ela estava errada e seu amigo, certo. Se digo que um filme ainda está em cartaz e outra pessoa diz que saiu de cartaz, basta consultar um jornal. Se dividimos a conta de um restaurante e chegamos a resultados diferentes, refazemos a conta ou usamos uma calculadora. Para inúmeros desacordos que nos acometem o tempo todo, temos meios de decidir quem tem razão, podemos julgar e nos pronunciar sobre o que está certo e o que está errado. Esse é um fato importante sobre nossas práticas epistêmicas comuns.

Mas, também é certo que muitos desacordos na vida cotidiana não parecem admitir uma solução. As pessoas conversam, discutem, argumentam e não chegam a um acordo. Esses são os desacordos "persistentes" (Elgin, 20IO). Em geral, na vida cotidiana, boa parte dos desacordos duram pouco, mas outros parecem infindáveis. Muitas vezes, eles se revelam persistentes, mesmo depois de muita discussão, porque as pessoas se aferram a um dos lados, por exemplo, por interesses políticos, econômicos ou religiosos. Uma tal discussão envolve a racionalidade com argumentos, mas leva em consideração outros fatores que fazem com que, propriamente falando, não haja uma investigação da verdade. Aqui, contudo, estamos considerando aquelas pessoas abriram mão de sua crença inicial e se dispuseram a investigar a verdade com base em argumentos. Se admitiram, no começo da investigaçáo, sua ignorância a respeito da verdade, e é precisamente por isso que se puseram a investigá-la, e se não lograram descobri-la, então elas reconhecem que estão no mesmo estado inicial de ignorância e que são incapazes de julgar quem tinha razão ou qual opinião é a verdadeira. Nesse caso, a atitude racional é suspender o juizo, isto é, depois de um exame cuidadoso no qual não encontramos uma razão clara para preferir um lado a outro da questão, mantemos a postura de não afirmar nem negar nada, até que novos raciocínios ou fatos talvez nos permitam resolvê-la.

Como, na vida cotidiana, há desacordos passíveis de soluçáo e outros que são persistentes e, talvez, insolúveis, pode-se dizer que os desacordos levam a uma suspensâo localizada do juizo, mas não abrangente, muito menos universal.

Também nas ciências, ao menos em algumas delas, os desacordos nos conduzem apenas a uma suspensão parcial do juízo. Decerto, há nelas desacordos que não raro 
se revelam persistentes, perdurando por muito tempo, até que se possa decidir sobre eles, quando se pode. Durante esse longo tempo, muitos cientistas suspendem o juízo, embora alguns possam apostar suas fichas nesta ou naquela hipótese. Se argumentos e experimentos, contudo, não decidem a favor de nenhum lado, como atesta o fato de que as apostas de cientistas se dividem entre as hipóteses conflitantes, a atitude racional parece ser a de suspender o juízo. No entanto, há razóes para pensar que essa suspensão do juízo nas ciências é limitada.

Talvez valha a pena, para entendermos melhor essa ideia, retomar a descriçáo dos períodos científicos feita por Thomas Kuhn (1970). Este distingue a ciência em quatro períodos: o pré-científico; o paradigmático; o período de crise; e o período revolucionário. No primeiro, reina uma balbúrdia, em que sobre tudo os cientistas se põem em desacordo: sobre as teorias, sobre os métodos, sobre os próprios fatos. Num determinado momento, porém, ao resolver um problema premente e crucial, uma teoria se impóe, com seus métodos e sua explicação dos fenômenos, tornandose um paradigma. Nem tudo, claro, é explicado e, aos poucos, outros problemas surgem, sejam empíricos, sejam teóricos. O período de crise, no qual as dificuldades se avolumam, tanto quantitativa como qualitativamente, acaba por gerar um período revolucionário, no qual se busca um novo paradigma. No entanto, diz Kuhn, uma vez que uma determinada área do saber se transforma numa ciência, nunca mais ela volta ao período pré-científico, isto é, por mais desacordos que existam entre os cientistas, nunca mais se volta ao completo desacordo inicial (Kuhn, 1970, p. I7). Portanto, a extensáo do descordo nas ciências está relacionada ao período em que uma determinada ciência se encontraria.

Não somente a extensão da suspensão do juízo é maior ou menor conforme o período científico, como também pode variar segundo o "eixo" de que se trata, pois uma ciência tem eixos teórico, empírico, metódico e de valores (Laudan, I984), sendo que os valores são tanto cognitivos quanto sócio-morais (Lacey, 2008). Os desacordos raras vezes atingem todos os eixos ao mesmo tempo. Assim, por exemplo, pode-se encontrar desacordo sobre uma determinada teoria, mas náo sobre determinados resultados científicos; pode haver desacordo sobre o método, mas não sobre a teoria; os valores sócio-morais podem ser controversos, mas não os cognitivos. Os desacordos são, assim, localizados quanto ao eixo, não atingindo toda uma ciência ao mesmo tempo, de modo que a restringir a abrangência da suspensão do juízo.

Em suma, a situação das ciências não se caracteriza por uma suspensão do juízo sobre toda a ciência, pois sempre há algum acordo entre os cientistas e nunca há um desacordo simultâneo sobre todos os eixos de uma determinada ciência. Náo quero subscrever aqui a nenhuma concepção específica de ciência, mas somente apontar para algo incontestável: nas ciências, há maneiras pelas quais a maioria dos cientistas acaba 
por se colocar, ao menos em boa parte, de acordo uns com os outros. Talvez se possa dizer que existe uma dinâmica da formação de crenças científicas pela qual se formam amplos consensos, mesmo que essa dinâmica possa ser bem difícil de descrever.

A dinâmica das crenças filosóficas, contudo, parece obedecer a uma lógica diferente da dinâmica científica (Kornblith, 20I3, p. 266-268; Searle 20IO, p. 23-25), ou de algumas delas. Em filosofia, é indispensável examinar ao menos os principais argumentos que sustentam cada uma das filosofias entre si discordantes. Essa é, com efeito, uma prática cotidiana e banal: ouvir todas as partes em conflito. Mas, na filosofia, essa prática é constitutiva do seu procedimento investigativo. Se se pode falar de um "método filosófico", esse método é argumentar dos dois ou mais lados de uma questão. Ora, sendo essa a dinâmica da filosofia, sendo a filosofia uma prática argumentativa dos dois lados de uma questão, explica-se por que muitos filósofos não somente não se perturbam com o desacordo, mas chegam mesmo a vê-lo como algo positivo: dada a generalidade da filosofia e o fato de que se busca uma verdade absoluta a respeito de entidades cuja existência não se estabelece ou se aceita por meios empíricos, o que náo ocorre nas ciências, o natural é que o debate não somente se perpetue, mas seja mesmo benéfico (Strawson,1985, vii-viii; Orlando, 2007, p. I39-I40). Mas não se trata, aqui, de caracterizar o desacordo como algo bom ou mau, mas de perceber que essa prática argumentativa parece implicar que a filosofia, por sua dinâmica própria, não tem nenhuma tendência a alcançar um acordo razoavelmente extenso e não pode alcançar uma verdade objetiva, se pretende isso.

É certo que um argumento visa a nos convencer de uma conclusão controversa. Curiosamente, o tiro parece sair pela culatra. Talvez seja uma inclinação natural que nós, diante de um argumento, nos oponhamos a ele; é como se um argumento, por si mesmo, nos convidasse a examiná-lo, a verificar suas premissas, a refletir sobre sua validade e, dessa maneira, a encontrar um argumento que lhe seja contrário. Assim, a prática essencialmente argumentativa da filosofia multiplica os desacordos ao infinito. Primeiro, temos um manifesto desacordo entre as diversas doutrinas filosóficas, em que teses e argumentos são explicitamente propostos uns contra os outros; quanto mais argumentam, tanto mais desacordos produzem. Segundo, quando se tenta identificar que uma determinada doutrina é verdadeira, argumentando-se com base numa suposta evidência, método ou critério, descobrem-se outros desacordos: sobre o que é evidente; sobre qual é o método filosófico; sobre os critérios a serem empregados. Para piorar a situação, quando se argumenta, com base em novas maneiras de filosofar, somente se estende o desacordo, porque o acordo inicial a respeito de uma maneira de filosofar simplesmente desaparece, dando lugar a um desacordo de um nível ainda mais alto. 
Poder-se-ia talvez pensar que o fato de não se chegar a um consenso se deve a uma desistência precoce da investigação filosófica: não se tentou suficientemente descobrir a verdade. Mas não é essa a experiência de quem se debruça com afinco e com paciência sobre as filosofias: quanto mais se estuda um assunto, tanto mais desacordos se descobrem. Portanto, os filósofos disputam sobre tudo que investigam, e sobre cada vez mais assuntos, porque vivem ampliando seus temas de investigaçáo. Quando se empreende séria e longamente uma tal investigação argumentativa, quando se amadurece com calma o pensamento em torno de um problema filosófico, sem precipitação, chega-se à conclusão de que os dois lados dispóem de bons argumentos, tão bons que é impossível tomar uma decisão, pois se anulam mutuamente.

Talvez se devam dizer algumas palavras sobre essa igualdade de forças. Não se trata, obviamente, de dizer que argumentos filosóficos têm uma força persuasiva intrínseca, pois essa seria uma concepção dogmática de um argumento. A força de um argumento depende, por exemplo, do interlocutor; ela é também relativa ao contexto em que o argumento é empregado. Tampouco há um critério para mensurar a força de um argumento, pois os dogmáticos estão em desacordo sobre os critérios e sobre eles o neopirrônico suspende o juízo. Como, então, o neopirrônico pode falar de uma igualdade de força? Ele "sente" a força desses argumentos? Em parte, sim. Não poderia, então, o dogmático invocar o fato de que ele "sente" a força de outra maneira? Pode. Mas, nesse caso, cada dogmático "sente" de maneira diferente. Um sente o argumento a favor de p como o mais forte; para outro, o mais forte é o argumento a favor de q; outro, sente que o argumento a favor de r é o mais persuasivo; outro pode "sentir" que s é sustentado pelo argumento mais forte. $\mathrm{O}$ fato mesmo de que cada um desses argumentos persuade um determinado grupo de dogmáticos mostra que cada argumento tem uma determinada força persuasiva. E como a comunidade filosófica se divide nessas diversas posiçóes (p, q, r, s), uma minoria enfrentando sempre uma maioria, percebe-se que nenhum argumento é mais forte que os demais, de modo que todos eles mais ou menos se equivalem. O cenário filosófico de disputa permanente atesta, portanto, que a força atrativa dos argumentos é parecida. Não é tanto a perspectiva individual que avalia a força persuasiva de um argumento, mas a divisão da comunidade filosófica revela esse equilíbrio da força persuasiva dos argumentos.

Pode-se mostrar de outra maneira que o desacordo, por si só, é insuficiente para levar à suspensão do juízo em todas as questóes filosóficas investigadas. Como vimos, diante de afirmaçóes filosóficas contrárias, a atitude racional é reconhecer a própria ignorância e investigar a questão. Pergunta-se, então, por que deveríamos aceitar esta doutrina, e não aquela. Ora, será preciso justificar a decisão, qualquer que ela seja. Mas tal justificação parece impossível, porque, nessa justificação racional, isto é, com 
base em razóes, ou incidimos num regresso ao infinito, ou num raciocínio circular, ou aceitamos uma hipótese arbitrária. Em outras palavras, o desacordo revela que as doutrinas filosóficas necessitam de uma justificação e, em seguida, nos damos conta de que é impossível dar razóes que justifiquem uma decisão. Se, em filosofia, o desacordo leva à suspensão do juízo, em parte é porque estriba sobre o regresso ao infinito, a circularidade e a hipótese arbitrária (Fogelin, 2016, p. I27-I28; 20I7, p. 158-I59). Mas, é claro, apontar um regresso ao infinito, mostrar a circularidade, revelar uma hipótese arbitrária são procedimentos que integram ou pertencem à prática que examina os argumentos dos dois ou mais lados de uma questáo.

Em suma, quem atenta maduramente para a dinâmica da investigação filosófica, destinada a produzir crenças, acaba por suspender o juízo. Somente com o auxílio inestimável da prática de oposição, o desacordo conduz à suspensão do juizo sobre todas as questóes filosóficas investigadas.

Objetou-se ao ceticismo, em qualquer uma de suas formas, portanto também ao pirronismo, que seria impossível viver segundo os princípios céticos, isto é, segundo o princípio cético de oposição que leva à suspensão do juízo: em vez de chegar à tranquilidade, o pirrônico seria levado à letargia e à morte, se fosse coerente com seus princípios (Hume, I986, p. I6I-I62); ou talvez a uma forma de vida insatisfatória, já que o pirrônico se desapegaria de todas as crenças e de tudo aquilo que torna a vida bela e atraente (Annas, 1993, p. 35I-363). A base dessa objeçáo é o pensamento de que a suspensão do juízo implicaria não considerar mais nada como verdadeiro, mas ficar contente somente com o que aparece. Quando diz algo, um cético náo pretenderia dizer uma verdade, mas táo somente expressar como as coisas lhe aparecem. Ora, sem ter nenhuma crença sobre como as coisas são, se o pão alimenta e a água mata a sede, como seria possível viver? Ou, se for possível viver, como poderia viver bem, com base apenas no que aparece?

Ora, corta-se o mal pela raiz, ao menos no que diz respeito à primeira forma da objeção, quando se deixa claro, como se fez na primeira seção, que a suspensão cética do juízo não incide sobre muitas crenças e opinióes da vida cotidiana. Vimos que não há uma suspensão do juízo sobre todas as questões, nem na vida cotidiana, porque de fato dispomos de muitos meios para resolvê-las nesse domínio, nem nas ciências, porque (para expressar-me de maneira simplificada) o método experimental, tâo diferente da prática de oposiçáo, abriu um caminho seguro para se estabelecer amplos consensos. Por isso, não creio que se possa dizer que todo discurso apofântico, isto é, toda afirmação que se pretende verdadeira, foi atingido, seja pelo desacordo persistente, seja pela prática de oposição. Ora, essas crenças banais sobre as quais nos pomos, ou podemos nos pôr, de acordo na vida cotidiana permitem ao neopirrônico viver sua vida sem nenhum problema. 
Mais difícil é responder à segunda forma da objeção, pois de que modo se poderia mostrar que uma vida de acordo com os princípios céticos é uma vida boa ou, como os pirrônicos antigos pretendiam, uma vida correta ( $\mathrm{PH}$ I.I7) e até uma vida mais feliz do que uma vida dogmática (M II.I40)? Como julgar isso? Como poderia um cético garantir que a sua filosofia produz uma vida mais feliz para todos os que se tornarem céticos? Suspeito que não se possa garantir isso, que cada pessoa é diferente das demais, que o que funciona para um pode não funcionar para outro; que o que pode ser uma regra geral num contexto histórico pode não valer para outro contexto histórico. As experiências humanas são muito variáveis. Com o intuito de descrever em linhas gerais como é, ou pode ser, uma vida neopirrônica, para que o leitor julgue isso por si mesmo. Partirei de uma reflexáo sobre o itinerário que leva um jovem filósofo a se tornar um filósofo maduro a fim de descobrir como a experiência intelectual da filosofia o transforma, detendo-me sobre o que ocorre nele para que ele se reconheça como um neopirrônico. Depois, direi algumas palavras sobre a vida do neopirrônico maduro.

Como não poderia deixar de ser, todos os jovens filósofos continuam a viver suas vidas enquanto investigam as questóes filosóficas. Enquanto ainda não chegam a nenhuma resposta definitiva, se é que chegarão a alguma, eles não têm razões para mudar substancialmente o que faziam, embora seja certo que uma vida dedicada aos estudos e à leitura dos livros dos filósofos já não é uma vida de todo igual à da maioria das pessoas. Durante essa investigação inicial, não há, propriamente falando, nenhuma diferença entre dogmáticos e céticos, pois a diferença entre eles reside no resultado dessa investigaçáo. Tendo passado por uma longa experiência intelectual propiciada pela filosofia, na qual, como vimos, a prática de oposição é um elemento chave, pode-se perguntar o que essa experiência produziu. Tudo depende de qual foi, exatamente, essa experiência intelectual, de como se praticou a oposição de doutrinas e argumentos.

Para uma questão filosófica formulada em seu nível mais alto de generalidade, por exemplo: podemos conhecer o mundo exterior?, há duas respostas principais: um veredito positivo, "sim, podemos"; e um veredito negativo, "não, não podemos". Se dermos um veredito positivo à questão sobre se há um conhecimento, existirão inúmeras doutrinas filosóficas que explicarão, cada uma à sua maneira, como esse conhecimento é possível, todas elas conflitando entre si em maior ou menor grau; se dermos um veredito negativo, então haverá apenas isso: um veredito negativo com os argumentos que o sustentam (Stroud, 1984). Essa questão sobre como o conhecimento é possível é uma questão menos geral do que a precedente, pois pressupóe uma resposta positiva à questão mais geral de todas. 
Com frequência, um jovem filósofo, quando se inicia na filosofia, se confronta com uma diversidade de doutrinas filosóficas, colocando-se a questáo menos geral do parágrafo precedente. Ele se pergunta: entre as doutrinas $\mathrm{A}, \mathrm{B}, \mathrm{C}, \mathrm{D}$ etc., qual é a verdadeira? A questáo tal como levantada, embora envolva o exame de diversas doutrinas em desacordo, sugere que alguma delas é a verdadeira e que o único problema é identificá-la corretamente. Um jovem filósofo é levado como que implicitamente a aceitar como correta uma resposta positiva à questáo mais geral. $\mathrm{O}$ equilíbrio e a imparcialidade da prática de oposiçáo se rompem quando, ainda no meio da investigação, ainda durante o exame das doutrinas dogmáticas em conflito, mas antes de investigar longa e cuidadosamente o que se pode dizer em favor de todas doutrinas, o jovem filósofo adere de maneira prematura a uma dessas doutrinas em conflito, porque, precisamente nesse momento, se sentiu persuadido por uma delas. A partir daí, sua investigação deixa de ser uma busca da verdade e adquire como que um caráter pedagógico: o de persuadir os demais da verdade de sua doutrina. Acostumado com a oposiçáo, ele adquire uma habilidade de lidar com ela, a de mostrar que um lado é mais forte que os outros. Para exercer essa habilidade, ele é treinado de certas maneiras, por exemplo, a exibir somente os argumentos mais fortes de sua doutrina, escondendo seus pontos fracos, ao passo que, no caso das doutrinas rivais, se concentrará nos pontos fracos e somente apresentará os argumentos fortes em uma versão caricata, a fim de poder responder-lhes (Bayle DHC, "Crisipo", G). Assim, o que a investigação filosófica produziu foi: a crença em uma determinada doutrina; um contentamento inicial consigo mesmo, por achar que obteve êxito na investigação; a habilidade em manipular argumentos para fazer parecer que um lado é o mais forte; um tormento constante, porque é uma tarefa ingrata tentar persuadir os demais dogmáticos da verdade de sua doutrina, porque essa tarefa parece nunca se cumprir.

Esses são, propriamente falando, os dogmáticos, aqueles que vieram a acreditar em alguma doutrina filosófica. Mas também é possível ao jovem filósofo experimentar a igualdade de forças entre as diversas doutrinas dogmáticas como insuperável de uma vez por todas. Nesse caso, ele é mais paciente, leva mais longe a sua investigação e consegue ver o equilíbrio quanto à força persuasiva das diversas doutrinas, não aderindo a nenhuma; mas extrai dessa incapacidade de decidir qual é a verdadeira uma conclusão precipitada, pois nega, então, que seja possível descobrir a verdade. E desistirá de buscar a verdade, porque se sentirá frustrado por chegar à conclusão de que não se pode descobrir a verdade e, insatisfeito, emitirá um veredito negativo, dizendo que nada é certo. Portanto, na oposição mais geral a que me referi acima, aquela entre um veredito positivo e um negativo, esse jovem filósofo não enxerga um equilíbrio, mas opta por um dos lados, o do veredito negativo. Ao assim proceder, esse jovem filósofo também interrompe sua investigação cedo demais, 
porque não se dá conta de que o veredito positivo também se apoia em bons argumentos, que, sendo igualmente convincentes, equilibram a disputa. Por isso, essa experiência intelectual tampouco é cética, embora somente a primeira seja propriamente dogmática (uma vez que somente no caso do veredito positivo se desenvolva uma doutrina filosófica); se se quiser chamá-la de uma forma de ceticismo, por não conter nenhuma doutrina específica e por rejeitar os dogmatismos, deve-se reconhecer que não se trata de um ceticismo pirrônico (Sexto PH I.I-4).

Mas o jovem filósofo que temos em vista aqui passou por uma experiência intelectual diferente dessas duas, pois não somente não aceitou nenhuma doutrina filosófica em particular, como também não desesperou de encontrar uma resposta; ele não deu um veredito positivo, nem um negativo. Numa palavra, ele suspendeu o juízo. O resultado imediato de sua prática filosófica é a suspensão do juízo em todas as coisas investigadas, seja sobre os diversos dogmatismos conflitantes entre si, seja sobre o veredito positivo e o negativo. Esse é o resultado da prática longa, imparcial e madura de oposiçáo, ao passo que a opçáo dogmática por uma doutrina filosófica é resultado de uma precipitação, talvez decorrente de um forte desejo de encontrar uma verdade, de uma pressão causada por aquela perturbação, ou ansiedade, inicial (Sexto PH I.I2). Uma vez que se tornou neopirrônico, nosso jovem aprende a controlar sua ansiedade. Assim, pode-se pensar que outro resultado da experiência intelectual do nosso jovem filósofo é uma atitude diferente: ele será mais cauteloso, menos precipitado, não dará seu assentimento a uma ideia nova que porventura possa lhe parecer sedutora, mas a examinará cuidadosamente, reservando seu assentimento para um momento posterior, caso não consiga reestabelecer o equilíbrio depois de longa e exaustiva investigação. Ele será, também, desconfiado das "verdades" que se propóem, suspeitará daqueles que proclamam "verdades" como se eles, somente eles, tivessem um acesso privilegiado a certas "verdades".

O que mais essa experiência intelectual típica do neopirronismo acarreta? Talvez se deva reconhecer, desde logo, que algo importante se produziu nele. Parece-me que se deve atentar para o impacto que a formaçáo filosófica de sempre examinar os dois ou mais lados de uma questão e, nessa prática prolongada, não chegar a nenhum veredito positivo ou negativo, causou no próprio filósofo. Essa prática produziu nele uma habilidade (Sexto PH I.8-II), a habilidade de argumentar de maneira igualmente persuasiva dos dois ou mais lados de uma questáo (Morison, 20II). O jovem filósofo não tinha essa habilidade quando começou a investigar filosoficamente; ele a desenvolveu conforme exercitou a oposição; e, como sempre chegava à suspensão do juízo, adquiriu-a por completo. Essa habilidade difere da habilidade do dogmático, pois o neopirrônico exibe todos os pontos fortes e fracos de cada doutrina, equilibrando-os. Esse é o resultado da prática sistemática de suspensão do 
juízo na qual se forma a mente de nosso neopirrônico: uma habilidade de opor de tal maneira que os dois ou mais lados tenham a mesma força persuasiva.

Nosso jovem filósofo, incansável e meticuloso em sua investigação filosófica, na qual se debruçou pacientemente sobre os dois ou mais lados de uma questão, tendo sobre todas as questóes investigadas suspendido o juízo, acostumou-se a pensar de uma determinada maneira. Essa determinada maneira de pensar, uma maneira cética de pensar, conduziu-o, na filosofia, à suspensão do juízo e, ao mesmo tempo, enquanto investigava, permitiu que continuasse a viver sua vida cotidiana, de um modo muito parecido ao de todos os homens (inclusive os dogmáticos), mas, em parte, de um modo que lhe é peculiar, pois não tinha nenhuma crença dogmática, bem como deixou de aderir a algumas das crenças e práticas do homem comum (pois reconhece que algumas resultam de um dogmatismo filosófico, religioso, ou de outra espécie, que se difunde na vida cotidiana). Em suma, a experiência intelectual do jovem filósofo que renovadamente suspende o juízo produz uma, por assim dizer, razão cética, a qual leva à suspensão do juízo na filosofia e orienta as ações na vida cotidiana (Sexto, PH I.I6-20). Embora eu fale de uma razão cética, isso não implica que essa razão seja única e idêntica, nem que seja a mesma para todos os neopirrônicos. $\mathrm{Na}$ verdade, em certo sentido, o neopirrônico dispóes de razóes (PH I.5). Para simplificar, falarei no singular.

O neopirrônico não perdeu o desejo de verdade por causa da suspensão do juízo sobre as doutrinas filosóficas. Nem todo discurso que se pretenda verdadeiro foi objeto de suspensão do juízo, somente o discurso filosófico. Afinal, nosso jovem neopirrônico não suspendeu o juízo diante de todos os desacordos. É certo que se exerceu também na vida cotidiana e nas ciências o mesmo espírito crítico maduramente treinado na filosofia, gerando uma atitude cautelosa, a qual muitas vezes leva à suspensão do juízo mesmo nessas esferas. Mas, tendo retido seu juízo a respeito de muitas supostas verdades na vida cotidiana e nas ciências, o filósofo suspensivo não deixa de continuar almejando a verdade ali onde ela ainda parece possível. Tanto na vida cotidiana quanto na ciência, pode-se investigar buscando a verdade. Nosso impulso natural para a verdade é, de fato, muitas vezes satisfeito. Portanto, a prática rigorosa e constante da oposição, não abole o desejo de verdade, como se poderia pensar e como usualmente se supóe. Tampouco na filosofia o neopirrônico deixará de investigar em busca da verdade. Embora já não creia mais que a posse da verdade é algo que está à mão, não deixa de pensar que a sua descoberta é pelo menos possível, sob pena de, caso afirme que é impossível descobri-la, incoerência, e que, dado nosso impulso à verdade, ainda vale a pena continuar a investigá-la.

Finalmente, a prática de oposição, repetida com rigor e paciência, produz por meio da suspensão do juízo uma tranquilidade (Sexto PH I.25-30), pois agora esse 
jovem filósofo perdeu aquela ansiedade que o levava a buscar a verdade. Esse foi um fruto inesperado de sua experiência intelectual, pois esperava que a descoberta da verdade trouxesse essa tranquilidade. De fato, naquelas questóes em que o desacordo não se revelou persistente ou insolúvel, mas para as quais chegou a uma conclusão, ele se sentiu satisfeito. Ele continuará a investigar a verdade, inclusive na filosofia, mas a condição de seu espírito na qual ele continuará sua investigação é uma condição serena, livre daquela ansiedade que a princípio o incomodava. E, como atingiu a desejada tranquilidade graças à suspensão do juízo, o neopirrônico exercerá sua habilidade de argumentar dos dois ou mais lados de uma questão de modo a equilibrá-los e, assim procedendo, fará dela o princípio fundamental que guia a sua investigação filosófica: a prática de oposição se converte em um princípio de oposição (PH I.I2-I5). Há, como veremos, um caráter normativo na razão cética.

$\mathrm{Na}$ sua vida cotidiana, é claro, muitos incômodos ainda o perturbarão, como o imposto de renda e as reuniôes de departamento e das comissóes das quais é membro. Aqui, uma tal tranquilidade é impossível; a moderação é o fim que uma razão cética se coloca na vida cotidiana. Afinal, o máximo que se pode esperar é que os aborrecimentos inevitáveis lhe incomodem o mínimo possível, com uma baixa intensidade, por assim dizer, e consiga desfrutar dos prazeres que a vida lhe oferece tanto quanto lhe é possível, sem se esforçar por um prazer desmesurado, o que implicaria esforços excessivos e, talvez, uma atitude obsessiva. Nessa medida, numa medida humana e relativa, a condição serena na vida cotidiana envolve sempre algum incômodo, mas não deixará de ser uma boa vida, desde que contemple prazeres amenos, como a leitura de um Tucídides, de um Tácito ou de um Shakespeare. Será, provavelmente, uma vida melhor do que a das pessoas comuns (M II.IIO-I3O), que não leem nada, e ainda melhor do que a dos dogmáticos (M II.I3O-I40), que quebram a cabeça para entender textos quase ininteligíveis.

Em suma, o grande impacto da prática constante e rigorosa da suspensão do juízo é uma espécie de razão, uma razão cética (Sexto PH i.I6-20). Com efeito, o conceito central para se entender a proposta neopirrônica é o de uma razão cética, porque é esse conceito que permite articular, de um lado, a crítica cética aos dogmatismos (sua habilidade, seu princípio fundamental) e, de outro, a forma de vida especificamente cética (seu critério, seus fins). Como vimos, a prática constante da oposição gera uma habilidade de argumentar dos dois lados de modo a suspender o juízo (Sexto PH I.8-II) e, quando continua sua investigação filosófica, o neopirrônico transforma essa habilidade num princípio de oposição, que norteará essa investigação (Sexto PH I.I2-I5). De outro lado, essa razão cética disporá de um critério, a saber, sua experiência-do-mundo, que serve para escolher algumas açóes e evitar outras 
(Sexto PH I.2I-24), garantindo tranquilidade na filosofia e a moderação na vida cotidiana, que são os fins do neopirronismo (Sexto PH I.25-30).

Mas as coisas não são tão simples assim. Objetou-se que, quando se torna neopirrônico, o jovem filósofo deve interromper sua investigaçáo filosófica, porque ele não mais busca a verdade, e sim a suspensão do juízo, já que esta, e não aquela, produz a tranquilidade, que é o fim último em vista do qual se faz a investigação. Ao transformar sua prática de oposição, sua habilidade de opor os dois lados de modo a equilibrá-los em um princípio, o neopirrônico abandona uma investigaçáo em busca da verdade, pois a partir de agora o que ele busca é a suspensão do juízo. Numa investigação filosófica aberta, não se sabe o que vai se encontrar; mas, numa investigação cética, sabe-se de antemão que o resultado será a suspensão do juízo. Ao contrario do que pretende e afirma, o neopirrônico náo continuaria a investigação filosófica. Repetiu-se essa objeção, com pequenas variaçôes nos argumentos, à saciedade. Por isso, vale a pena retomar o assunto.

Uma primeira resposta poderia ser a seguinte. $\mathrm{O}$ neopirrônico náo pode dizer que é impossível descobrir a verdade, pois seria abandonar seu ceticismo; por ter suspendido o juízo, entende que ainda é possível descobri-la; portanto, mesmo que busque a suspensão do juízo, ele deve estar atento à possibilidade de descobrir a verdade. Se isso for correto, pode-se perguntar: como o neopirrônico continua sua investigação filosófica? Embora não difira muito da primeira investigação, a investigação continuada apresenta algumas diferenças importantes. Em ambos os casos, reconhece-se, no ponto de partida, que não se sabe qual é a resposta à pergunta filosófica: no caso do jovem filósofo, porque ele apenas se inicia na filosofia; e, no caso do neopirrônico, porque ele suspendeu o juízo. Nos dois casos, o objetivo da investigação é a verdade, mas, enquanto o jovem a busca com grande esperança, o neopirrônico não tem mais essa ilusão, pois sabe das dificuldades de encontrá-la. Além disso, ambos investigam os dois ou mais lados da questão, sendo que essa prática de investigar dos dois lados de uma questão se transforma, como acabamos de ver, num princípio que guia a investigação filosófica; ora, no caso do jovem filósofo, essa prática acabou por levá-lo a suspender o juízo e, como que por acaso, à tranquilidade, ao passo que o neopirrônico, guiado por esse princípio, interrompe provisoriamente a sua investigação no momento exato em que os dois ou mais lados de uma questáo se equivalem. O neopirrônico evita qualquer decisão precipitada e, quando suspende o juízo, é somente para poder continuar investigando depois, sem fechar a questão, — nem antes, nem depois; com paciência e dedicação, ele dará a devida atenção a todos os lados, até que eles se equilibrem, de modo que possa continuar sua investigação sobre outros tópicos. 
A objeção, entretanto, não perguntava como o neopirrônico continua sua investigação filosófica, mas como é possível continuá-la, dado que, se quer alcançar a tranquilidade e o meio para a tranquilidade é a suspensão do juízo (a crença na verdade só traz mais ansiedade), o neopirrônico tem de desistir da busca da verdade; haveria como que uma contradição entre buscar a verdade e buscar a tranquilidade. O problema reside no princípio fundamental do neopirronismo, que é o da oposição. É preciso explicar como um princípio que orienta a investigação em busca da suspensão do juízo pode dar lugar também à busca da verdade, já que, se sempre suspendermos o juízo, jamais teremos uma crença a respeito do que é verdadeiro.

Para responder a essa objeção, teremos de investigar melhor a relação entre investigação, suspensão do juízo e tranquilidade e mostrar por que buscar a verdade e buscar a tranquilidade não se opóem. Tracemos a distinção entre ter por fim a tranquilidade e ter por objetivo a verdade (Barney, 20I8), em vez de pensar somente que a verdade (ou a suspensão do juízo) é somente um meio para o fim proposto. Uma investigação filosófica tem um objetivo que lhe é intrínseco, que é descobrir a verdade, e um fim que lhe é extrínseco, que é eliminar a perturbação que motivou a investigação e produzir a tranquilidade.

Concentremos nossa atenção, por um momento, no fim da investigação. Ambas as investigaçôes (a inicial do jovem filósofo e a continuada do neopirrônico) têm como fim a tranquilidade, mas enquanto o jovem filósofo ainda não está tranquilo, mas precisa alcançar essa condição, de modo que a tranquilidade deve ser um dos resultados dessa investigação, o neopirrônico já alcançou esse estado e a continuidade dessa investigação não se faz mais para produzir a tranquilidade, embora se faça tendo em vista a tranquilidade, isto é, ao suspender renovadamente o juízo, reforça-se sua condição tranquila. Noutras palavras, a origem da investigação inicial do jovem filósofo é a perturbação ou ansiedade, ao passo que a investigação continuada não se faz mais para produzir a tranquilidade, mas somente para preservá-la. A ausência dessa ansiedade inicial que levou uma pessoa a filosofar contribui para que a investigaçáo filosófica do neopirrônico se faça sobretudo em benefício da verdade, uma vez que não há mais a pressão causada pela ansiedade para que se alcance logo a verdade. A condição tranquila é precisamente o que permite uma investigação longa e ponderada, na qual só se dê o assentimento quando a verdade como que brilhar por si mesma; a condição tranquila é o que assegura uma busca da verdade sem parcialidade. Longe de se excluírem, elas se complementam.

Essa observação tem um lado reverso. Essa origem da investigação filosófica (uma perturbação) vale não somente para o neopirrônico, mas para qualquer filósofo, inclusive para os dogmáticos; destarte, o assim chamado "princípio causal" (PH I.I2) 
não diz respeito somente à origem do ceticismo e não lhe é de modo nenhum específico. Os dogmáticos também começam a filosofar porque querem eliminar uma perturbação. Mas os dogmáticos, ao contrário dos neopirrônicos, multiplicam os desacordos em suas infindáveis disputas e, não resolvendo nenhuma questáo, acabam por elevar o grau inicial de ansiedade e, consequentemente, tornam a necessidade de uma decisão ainda mais premente e, por isso mesmo, sua decisão se revela com frequência cada vez mais apressada.

Essa observação inicial, embora importante e pouco notada, não basta para explicar como o neopirrônico pode continuar sua investigação filosófica. Uma coisa é investigar com serenidade, outra é buscar a suspensáo do juízo no lugar da verdade e a primeira não evita a segunda, pois ainda é preciso ao menos manter a tranquilidade. A busca da suspensão, mesmo que somente para preservar a tranquilidade, não impediria a busca da verdade? Não, não impede, pois não há contradiçáo entre ter por fim a tranquilidade e buscar a verdade (Perin, 20I0, capítulo I). Uma das razóes para isso é que nunca se buscou a verdade somente como um meio para a tranquilidade; assim, se a verdade deixa de ser considerada um meio para a tranquilidade, nem por isso ela perde inteiramente sua atratividade, pois podemos querer a verdade por outras razóes; por exemplo, por curiosidade intelectual ou porque a verdade nos permite interferir e controlar melhor o mundo.

Mas dizer que não há contradição entre o fim e o objetivo é somente parte da resposta. É preciso entender ainda como a razão cética, apoiada num princípio cético, orienta a habilidade cética numa investigaçáo que tem por objetivo a verdade e como fim a tranquilidade. Nesse sentido, ao lado do fim e do objetivo, é preciso introduzir as ideias de um término e a de uma interrupçáo temporária da investigação. O dogmático termina definitivamente sua investigação, quando um dos lados o persuade e ganha o seu assentimento; nesse preciso momento ele póe um termo ou ponto final em sua investigaçáo, pois não mais a retomará, porque, como vimos, a ignorância ou suspensão do juízo é uma condição necessária da investigação e o dogmático não cumpre essa condição ( $\mathrm{PH}$ 2.II; Friedman 20I5); como se diz, "o caso está encerrado” e só pode ser reaberto, caso o dogmático abandone sua crença. O neopirrônico, por sua vez, interrompe sua investigação naquele preciso momento em que os dois lados de uma investigação se equivalem; ora, essa interrupção não é nem precisa ser permanente, porque não viola uma condição necessária da investigaçáo; ao contrário, preserva-a. E é justamente com o intuito de preservá-la que o neopirrônico interrompe sua investigação no momento de equilíbrio, porquanto assim poderá retomá-la mais adiante, se quiser; o caso não está encerrado, mas continua sub judice. Não somente ele suspende o juízo e reforça sua tranquilidade, como 
ele garante uma condição necessária da investigação. Ao fazer uma interrupção temporária, quando os lados se equilibram, o neopirrônico se permite também passar para a investigação de outro assunto. Portanto, conforme vai equilibrando os lados de uma questão, o neopirrônico vai passando de um assunto a outro: assim que interrompe temporariamente uma investigação, ele começa outra. É dessa maneira que a razão cética orienta a investigação filosófica do neopirrônico, ditando-lhe, por meio de interrupçóes temporárias, seu ritmo e sua ordem. Não há outra maneira de continuar a investigação acerca da verdade se não suspendendo o juízo. $\mathrm{O}$ neopirrônico se vê como o guardião da investigação filosófica, não como aquele que lhe póe uma pá de cal. A interrupção cética é uma parada no trajeto em busca da verdade: ao parar numa estação, o neopirrônico pode continuar sua viagem; o dogmático, no entanto, por achar que chegou na estação final, desembarca e não mais continua a sua viagem. Mas, diz o cético, o dogmático desembarcou antes da estação final. Por isso, segundo o cético, sua atitude é precipitada. De fato, as disputas continuam e é preciso continuar investigando.

E como pode uma razão cética orientar uma vida cética? Se, por um lado, uma razão dogmática se apoia na doutrina que pretensamente estabeleceu, por outro uma razão cética não pode se apoiar em nenhuma doutrina desse tipo. Um critério cético de ação não pode ser uma doutrina filosófica. Não é dessa maneira que uma razão cética pode orientar uma vida cética. Uma razão cética propõe, como critério para a conduta da vida, a experiência-do-mundo. Tanto quanto a experiência intelectual do equilíbrio entre dois ou mais lados foi decisiva na investigaçáo filosófica, também na vida cotidiana a experiência-do-mundo desempenhará um papel crucial. O neopirrônico, portanto, vive sua vida seguindo a experiência-do-mundo. $\mathrm{O}$ que isso significa?

Antes de tudo, o neopirrônico reconhece que sua ação ocorre no mundo natural e social em que está imerso, que há objetos materiais, animais e pessoas com os quais interage de diversas maneiras; e essa ação se guia por uma experiência-do-mundo, por uma experiência em relação às coisas no mundo físico e às pessoas na sociedade em que ele vive. A ideia mesma de uma experiência-do-mundo só tem sentido se pressupusermos essas outras ideias: a ideia de um mundo e seus objetos e eventos; a ideia de pessoas e suas percepçôes; a ideia de relaçóes entre o que existe no mundo. Daí o hífen na expressão "experiência-do-mundo": para evitar a tentação, se tentação houver, de entender o critério neopirrônico de ação como algo subjetivo, como uma mera representação do mundo externo ou como mera afecção passiva que as coisas produzem em nós; ou de entender a "experiência-do-mundo" como um conceito básico, como um conceito do qual os demais dependem, mas que ele próprio não depende de nenhum. Quando propõe a experiência-do-mundo como critério de ação, o neopirrônico já dispóe de uma razão cética que institui um princípio de 
oposição na filosofia, baseado numa habilidade adquirida ao longo de sua formação filosófica, e que vai agora instituir essa experiência-do-mundo como critério, porque ele continuou, enquanto investigava filosoficamente, vivendo a sua vida como sempre a vivera.

Dependendo do sentido da expressão, pode-se dizer que uma experiência-domundo é e não é algo "dado". A experiência-do-mundo é um dado, no sentido em que há algo que se lhe impõe: por exemplo, ao abrir os olhos, o neopirrônico não se escolhe o que vê, se uma bela praia ou a vista do bairro dos Pimentas. Mas ele não adere a nenhuma doutrina positivista do dado, de modo que não é vítima do "mito do dado" ou de alguma forma de reducionismo, porque, noutro sentido, a experiência-do-mundo está associada à linguagem. Aprendemos a dizer certas frases diante de certas situaçôes (a dizer "essa árvore está florida" quando a árvore está florida) e nossa experiência-do-mundo é condicionada, em parte, por nossos conceitos. Pode-se dizer, num linguajar filosófico, que nossa capacidade perceptiva depende de nossa capacidade conceitual, ou de nossa capacidade para julgar (Stroud, 20I8b). Pode parecer que uma tal concessão a esse linguajar implica alguma forma de idealismo (McDowell, 2007), como se a linguagem fosse um "ingrediente constitutivo" ou permeasse essa experiência, mas não implica, nem mesmo um idealismo transcendental (Stroud, 20I8a), porque a experiência-do-mundo é uma experiência no mundo.

Nem implica dogmatismo, porque não se trata de enunciar uma "lógica" ou uma "estrutura" da experiência-do-mundo, como se fosse possível ao neopirrônico sustentar uma doutrina sobre essa experiência-do-mundo. $\mathrm{O}$ neopirrônico insistirá que, ao falar de uma experiência-do-mundo, não confere nenhum privilégio ao "eu", mas também não admite nenhuma realidade independente e absoluta, como querem os dogmáticos. Afinal, a experiência-do-mundo que orienta o neopirrônico em sua vida não é somente sua experiência pessoal do mundo, mas uma experiência humana em grande parte compartilhada e que ele herda de seus semelhantes; essa experiência-do-mundo não ocorre em um mundo de coisas em si, mas nesse mundo que experimentamos, que está ao nosso redor e que faz parte da nossa vida. No primeiro caso, o neopirrônico se reconhece como um ser humano entre outros seres humanos, não havendo nenhuma necessidade de explicar como se passaria de sua experiência pessoal do mundo para uma experiência comum do mundo; no segundo caso, ele reconhece somente esse mundo comum do qual sempre falamos e no qual sempre vivemos, sem precisar dar nenhuma explicaçáo de como esse mundo não é uma "realidade absoluta".

Pode, entretanto, o neopirrônico fazer afirmaçóes sobre o mundo? Parece que não. Vimos que o neopirrônico adota uma atitude cautelosa. Tendo desconfiado de todas 
as doutrinas filosóficas e evitado a precipitação e a arrogância dogmáticas, o neopirrônico não faria sequer afirmaçôes sem convicção. Enquanto um dogmático asseguraria com firmeza que tal coisa é verdade, o neopirrônico somente expressaria a sua opinião. Assim, um neopirrônico poderia se sentir tentado a dizer que o seu discurso não é "sobre" a realidade, não é uma "afirmação" que assegura como as coisas são, mas é somente uma "expressão" de sua experiência irrecusável (Barnes 1998, p. 65-67). Sugere-se, entấo, que o verbo "ser" deveria ser eliminado do discurso neopirrônico, se propriamente entendido. Em vez de dizer coisas como "o mel é doce", o neopirrônico diria "o mel aparece doce (para mim)", relativizando o aparecer a quem aparece. O domínio do aparecer, dessa perspectiva, não se limita a coisas ou propriedades, mas os fatos mesmos nos apareceriam, de modo que seria ainda mais correto dizer "Aparece-me que o mel é doce". Dessa forma, o verbo "ser" não precisa ser eliminado do discurso cético, mas deve ser necessariamente compreendido em relação a quem o aparecer aparece. $\mathrm{O}$ risco de dogmatismo parece, então, evitado, sempre que se puser, antes de toda e qualquer afirmação, o operador "Aparece-me que...”.

Não me parece, entretanto, que o neopirrônico abra mão de uma concepção comum de seu discurso cético, na qual se fazem afirmaçóes, como se uma concepção filosófica devesse ocupar o seu lugar, substituir-lhe, como se estivesse limitado a expressar o que lhe aparece. Tal substituição levaria o neopirrônico a uma série de dificuldades desnecessárias. Primeiro, essa absorção, por assim dizer, do verbo "ser" pelo verbo "aparecer" sugere, se não uma supressão da realidade objetiva, ao menos uma estratégia reducionista. Já vimos que o neopirrônico rejeita qualquer forma de reducionismo. Segundo, dir-se-á que não pode existir uma linguagem que seja somente expressiva, que saber usar frases como "aparece-me que p" depende de saber usar "p". Terceiro, muitos dirão que tal manobra trivializa o ceticismo, pois bastaria sempre dizer "Aparece-me que..." e, depois, dizer qualquer coisa, como "Apareceme que os deuses existem" ou "Aparece-me que São Paulo é uma cidade linda". Para esses críticos, o ceticismo, ao invés de ser uma filosofia crítica, torna-se um escudo protetor de todos os preconceitos, vestidos com a roupagem do "Apareceme que...”. No melhor dos casos, portanto, aquela explicação filosófica sobre os verbos "ser" e "aparecer" serve somente para evitar possíveis mal-entendidos quando o neopirrônico conversa com o dogmático, nunca para substituir a ideia comum de que, ao falar como todo mundo, ele faz afirmaçóes, isto é, como se ele somente fingisse fazer afirmaçóes, mas, propriamente entendido, não as faria.

O neopirrônico faz afirmaçôes como todo mundo: se diz "o mel é doce", essa afirmação é sobre a doçura do mel. Como adere à experiência-do-mundo, o neopirrônico não suspende o juízo sobre afirmaçóes banais como "Ontem, choveu tanto que algumas partes da cidade ficaram alagadas" e "O São Paulo perdeu novamente"; 
quando acontecem essas coisas, aquelas afirmaçôes são consideradas verdadeiras, embora tristes. O neopirrônico suspende o juízo sobre as doutrinas filosóficas sobre o tempo e o espaço, sobre o mundo exterior e sobre a causalidade; mas isso não implica suspender o juízo sobre eventos que aconteceram ontem em tal lugar, nem sobre a água ou sobre o que causou a inundação. Vimos que o desacordo na vida cotidiana não leva a uma suspensão do juízo sobre todo discurso apofântico.

O discurso comum de que o neopirrônico sempre se serviu e continua a se servir é "sobre" a realidade, esse discurso serve para dizer "como as coisas são". Correspondentemente, o discurso dogmático não é sobre a "realidade", mas é sobre uma "realidade independente", "em si mesma” ou "absoluta”, o que, no vocabulário dogmático, não é equivalente à realidade a que nos referimos no discurso comum, a qual, nesse vocabulário, seria uma "mera” aparência. Assim, pode-se caracterizar o discurso dogmático como "tético", isto é, como postulando algo além dessa realidade da qual falamos em nossas vidas cotidianas, dos objetos usuais de referência do nosso discurso ordinário, ao passo que se pode caracterizar o discurso neopirrônico como "não tético”, isto é, não postulando nenhuma outra realidade. É preciso desvincular o caráter afirmativo de um discurso de seu caráter tético, porque este caráter tético pertence somente ao discurso que postula uma dimensão além deste mundo que experimentamos, não à afirmação. O discurso comum é, em boa parte, um discurso afirmativo, e não meramente expressivo, mas tampouco é tético. Ao aderir às práticas linguísticas em sua experiência-do-mundo, o pirrônico adere à prática de fazer afirmaçôes.

Mas, poder-se-ia insistir, não terão essas afirmaçôes comuns pretensôes absolutas? Ao reconhecer que se está fazendo afirmações sobre o mundo, o neopirrônico não estaria abandonando o seu ceticismo? Acho que não. Ao admitir que suas afirmaçóes têm pretensóes de verdade, o neopirrônico não precisa qualificar essa verdade de "absoluta"; nem precisa apressar-se em dizer que a verdade é sempre "relativa”, para evitar o mal-entendido de que estaria incidindo no dogmatismo. Ele não dirá nem que a verdade de suas afirmaçóes comuns, se e quando forem verdadeiras, é "absoluta", nem que é "relativa". Tampouco se manifestará, como acabamos de ver, sobre o tipo de realidade a que se refere, se em si mesma ou se fenomênica, se dependente ou independente de uma mente etc. O dogmático quer que o neopirrônico se posicione diante de suas questôes tipicamente dogmáticas. Mas não há por que cair nessa armadilha.

O neopirronismo está a léguas de distância do assim chamado ceticismo cartesiano (Fogelin, 2004, p. I62-I65; 2016, p. I24-I25; 2017, p. 249-25I). Há várias razões invocadas pelo neopirrônico para afastar-se dessa suposta forma de ceticismo. Mencionarei a principal. Para se levantar a chamada dúvida cética sobre o mundo exterior, é preciso supor uma distinção entre um mundo mental interno e um mundo 
físico externo; essa distinção, no entanto, é dogmática. Além disso, interpretar a experiência-do-mundo como uma modificação da mente ou uma representação mental é também uma doutrina dogmática. O que o filósofo cartesiano faz, de modo supostamente cético, é duvidar sobre o nosso conhecimento do "mundo exterior", enquanto preserva o "mundo interior" ao abrigo de sua dúvida. Entretanto, essa dúvida é, de um lado, dogmática, porque pressupóe doutrinas dogmáticas sobre a mente e suas representaçóes, e, de outro, não é universal, porque não atinge o conhecimento de si mesmo. O neopirrônico investiga e suspende o juízo sobre a mente, se é material ou não, e sobre a representação, se é mental ou não.

A valorização do fenômeno (phainómenon) como noção chave do pirronismo antigo abriu as portas para uma aproximação entre essa vertente do ceticismo e o ceticismo moderno inaugurado por Descartes, já que a noção de fenômeno não é tão clara quanto se desejaria. Pagar esse tributo à terminologia dogmática clássica tem o seu preço. As interpretações são controversas, mas é plausível a assimilação do fenômeno à representação (phantasía) e à afecção (páthos). Diversos importantes estudiosos do pirronismo antigo defendem essa interpretação. Se o neopirronismo se articular em torno da noção de fenômeno, então será preciso enfrentar o desafio de mostrar que o fenômeno não se reduz à representação ou à afecção. De qualquer forma, se o neopirronismo quer afastar-se do ceticismo cartesiano, o melhor a fazer é não articular seu neopirronismo em torno do fenômeno. Nesta proposta neopirrônica, o conceito chave é o de razão cética, enquanto a ideia correspondente, mas não idêntica, de experiência-do-mundo ocupa somente um lugar secundário. Lembremo-nos de que há uma proposta neopirrônica importante em que a noção de fenômeno sequer aparece (Fogelin, 20I7).

Claro, um neopirrônico consistente jamais poderia fazer essa identificação entre fenômeno e representação ou afecção. Isso não significa, contudo, que o neopirrônico recuse a ideia mesma de representação, dado que só recusa as doutrinas filosóficas da representação, aquilo que os dogmáticos dizem da representação. $\mathrm{Na}$ vida cotidiana, falamos de representação com frequência: não só a representação política ou estudantil, por exemplo, os representantes dos professores adjuntos numa determinada comissáo, mas também das representaçóes que estáo nos teatros, nos museus, nas pinturas, nas fotos, nos romances. Faz parte de nossa concepção do mundo que uma parte do mundo possa representar outra parte do mundo. Modelos são construídos para representar uma parte da realidade; é para isso que servem. Nada disso, entretanto, implica pensar que tudo a que temos acesso seriam experiências-do-mundo entendidas como "representaçóes mentais" de uma "realidade independente", "absoluta” ou "externa à mente”. No entanto, se um dogmático aceita 
uma teoria da representação, nada impede que o neopirrônico lance mão dos argumentos do cético cartesiano para confundi-lo (Fogelin, 2004, p. 165).

Distinguindo-se do cético moderno, o neopirrônico procura mostrar que, longe de privilegiar a perspectiva individual, ele se vê inserido num mundo maior ao qual pertence. Nada poderia ser mais adequado a uma visão neopirrônica do mundo. Tanto quanto posso ver, esse difícil equilíbrio entre o reconhecimento de nossa inelutável perspectiva individual e o nosso pertencimento a um mundo natural e social é bem apreendido pela descrição do neopirrônico: nós tanto ocupamos um lugar num mundo espaço-temporal, quanto percebemos esse mundo de nossa perspectiva localizada (Strawson, 2002, capítulo 5). O “eu”, para retomar um pronome pessoal entre outros, mas sobre o qual os dogmáticos insistiram tanto, é um ser humano, como outros seres humanos (Strawson, 2019, capítulo 3). Também aqui o neopirrônico não tem nenhuma antropologia filosófica a oferecer, mas somente explicita nossa concepção comum.

Talvez seja difícil desdobrar a ideia de uma experiência-do-mundo em uma série de aspectos, cada um dos quais revelando uma característica importante da conduta cética. É certo que o neopirrônico emprega seus sentidos e seu entendimento para agir: se ele vê uma árvore no seu caminho, dela se desvia. Não pode deixar de seguir seus instintos naturais: se tem sede, beberá água. Como também não pode ignorar leis e costumes de seu país: deve pagar imposto de renda todo ano e veste-se de maneira adequada para as diferentes ocasióes. Finalmente, tem uma formação profissional, um emprego ou ofício, que lhe permite fazer muitas outras coisas: se é médico, poderá prescrever a medicação adequada. Esse é um esboço rudimentar que mal descreve como o neopirrônico vive e que poderia ser ampliado.

Esse esboço, no entanto, é suficiente para indicar que a vida de um neopirrônico é, em boa parte, convencional. Como continuou vivendo todo esse tempo sua vida cotidiana segundo suas crenças comuns, o neopirrônico continuará com muitas dessas crenças comuns. Decerto, aquelas crenças que ele tinha e que dependiam de alguma forma de dogmatismo foram, na medida de suas forças, eliminadas. Nem todas as crenças que tinha ao iniciar sua investigação filosófica, ele as terá ao seu final. E muitas outras crenças dogmáticas que lhe passaram despercebidas, pois o dogmatismo é insidioso e insinua-se em nossa visão do mundo, poderão ser eventualmente abandonadas, com o constante e disciplinado exercício da razão cética. Em medida não insignificante, portanto, o neopirrônico não agirá como muitos de seus semelhantes.

Quando o neopirrônico age com base no que pensa, ele de fato crê naquilo que pensa. Sua crença pirrônica náo é um mero reconhecer do que lhe aparece em sua experiência, mas é uma crença a respeito do que se passa no mundo, do que é real; ele pensa que o que afirma é verdadeiro. Se toma um remédio para aliviar uma dor, o 
neopirrônico crê que aquele remédio tem um determinado efeito sobre o seu corpo e, portanto, que sua dor passará. Pode ser que a dor não passe, mas essa é outra história. O importante é ressaltar que a ação neopirrônica não é um mero faz de conta, uma ação oca que não pressupóe nenhuma crença cética. Ao contrário, o neopirrônico engaja-se na ação tanto quanto qualquer outra pessoa, comum ou filósofa.

O neopirrônico crê, e crê no sentido usual da palavra "crer", isto é, ele pensa que suas crenças são verdadeiras, ele não dissocia "crença” e "verdade": para ele, crer em alguma coisa é crer que essa coisa é verdadeira. Embora possa se tratar de uma disputa sobre palavras, pretender que se possa ter uma crença sem pretender que essa crença seja verdadeira parece distorcer o significado comum da palavra "crença". A dissociação entre crença e verdade parece abolir a própria ideia de crença, pois não há crença se não houver uma pretensão, em algum grau, da verdade dessa crença (Fine 2000, p. 82-88). Não é uma boa razão recusar a conexão entre a crença e a verdade somente porque filósofos dogmáticos usaram a palavra "crença" de uma maneira muito específica, exigindo-lhe uma fundamentaçáo e uma justificaçáo. Além disso, o mero reconhecimento da experiência não consiste numa crença, ao menos se estivermos usando a linguagem comum; no melhor dos casos, consistiria na crença de que se tem tal experiência, mas não de que o mundo seja assim ou assado.

O neopirronismo tem uma característica peculiar, pouco desenvolvida no pirronismo antigo, se é que foi desenvolvida. Ao lado da tarefa terapêutica, há a tarefa positiva de elaborar uma "visão cética do mundo" (Smith, 2017, p. I57-I96). Esta seria concebida como uma explicitação discursiva da experiência-do-mundo. A investigação neopirrônica não está confinada ao combate ao dogmatismo, não somente porque em sua investigaçáo filosófica o neopirrônico busca a verdade, mas também porque sua investigação filosófica pode produzir resultados positivos, tanto no que diz respeito a essa explicitaçáo discursiva de sua experiência-do-mundo quanto no que diz respeito a questóes filosóficas que podem ser tratadas empiricamente ou, pelo menos, que lidam com problemas da nossa vida.

Essa visão cética do mundo é complexa. Primeiro, ela tem dois aspectos: um pessoal e outro comum. É certo que as crenças têm um aspecto pessoal, que dependem da trajetória de cada um, inclusive de cada cético. Assim, essa visão variará de um cético para outro, não somente entre céticos de épocas e lugares diferentes, mas mesmo entre céticos que pertencem a uma mesma sociedade. Mas não é menos certo que compartilhamos muitas coisas com nossos semelhantes e que, recebendo a mesma formação e instrução, vivendo mais ou menos nas mesmas condições e circunstâncias, muitas opiniôes serão compartilhadas. Os filósofos se referiram a essas crenças comuns como constituindo um "esquema conceitual" e ao modo como se articulam como a "estrutura do nosso pensamento". Parece-me que as opinióes 
compartilhadas são, num determinado sentido, mais fundamentais que as crenças pessoais, porque estas só podem emergir sob o pano de fundo daquelas. Uma visão neopirrônica do mundo não pode dispensar uma explicitação dessa estrutura conceitual comum, uma espécie de "metafísica descritiva" como sua tarefa primeira e central (Strawson, 2019). Nem por isso se deve diminuir a importância da ideia de que a visão cética do mundo comporta um inegável aspecto pessoal, que toda visão cética é uma visão e que esta diferirá de um cético para outro em diversos pontos, inclusive em pontos importantes. Afinal, essa mesma explicitação da estrutura do nosso pensamento poderá diferir de neopirrônico para neopirrônico.

Também se deve reconhecer que uma visão cética do mundo tem, como seu núcleo, embora de contornos imprecisos e permeável, uma dimensão cotidiana, que comporta tanto crenças pessoais, como comuns. Mas ela tem, ainda, outras dimensóes, como a científica e a filosófica, que igualmente podem comportar crenças pessoais e comuns. Como é uma pessoa bem instruída, que acompanha os resultados científicos, o neopirrônico poderá incorporar, em sua visão cética do mundo, aqueles resultados produzidos pelos cientistas. É certo que muitos desses resultados já foram incorporados numa visão comum do mundo, como o fato de que a Terra é redonda, e não plana, e gira em torno do Sol, e não está parada no centro do mundo. Mas a ciência formula, incessantemente, novas hipóteses e confirma outras já aventadas, de forma que o neopirrônico, conforme a sua formaçáo e a sua curiosidade, poderá ampliar e alterar sua visão cética do mundo à luz das ciências. Ora, como o conhecimento do mundo se faz com base em nossa experiência-do-mundo e a ciência empírica metodiza e corrige nossas práticas cotidianas, uma visão cética do mundo mais sólida e confiável será aquela que incorpora nossas melhores investigaçôes empíricas do mundo, isto é, não se dissocia das ci6encias empíricas; isso decorre naturalmente de uma concepção empirista do conhecimento.

E, sendo filósofo, o neoprrônico poderá dedicar-se a muitas questóes filosóficas que não têm caráter dogmático (muitas não o têm) ou a questóes que, embora tenham sido tratadas dogmaticamente, poderiam não ser tratadas assim. Já aludi ao fato de que uma tarefa indispensável é a explicitação daquela estrutura do nosso pensamento sobre o mundo. Ora, essa explicitaçáo é sobremaneira difícil e, sendo abstrata e envolvendo muitas dificuldades, diferentes neopirrônicos podem propor diferentes explicitaçóes. Além disso, sobre diversos problemas filosóficos, talvez seja possível propor soluçóes que não são dogmáticas, como por exemplo soluçóes para problemas em filosofia da ciência. Sugeri, há pouco, que o neopirrônico é um empirista. Assim, à visão cética do mundo se podem integrar crenças filosóficas empiristas, desde que não dogmáticas (pois há formas dogmáticas de empirismo). 
Mas a dimensão da vida cotidiana é fundamental; sem ela, não haveria uma dimensão científica ou filosófica; porque as ciências e a filosofia são atividades feitas pelos seres humanos em suas vidas.

Ao elaborar a descrição de sua visão cética do mundo, o neopirrônico não precisa se inibir e evitar o vocabulário da verdade, da realidade e do conhecimento (Fogelin 20I7, p. 252-254). Embora eu já tenha insistido bastante nessa ideia, cabe retomá-la aqui, porque um neopirrônico poderia se sentir tentado a não usá-lo ou, caso o use, talvez se sinta obrigado a explicar-se e dizer que "verdade", "realidade" e "conhecimento" são, bem entendidos, relativos a nós. No seu uso comum, palavras como "verdade", "realidade" e "conhecimento" se referem ao mundo a como o mundo é, não a um "mundo fenomênico" em oposição a um "mundo das coisas em si mesmas”. Usar esse linguajar aparentemente mais cauteloso pode, às vezes, prestar-se mais a confusôes do que a esclarecer a posição neopirrônica, porque parece retirar das expressóes comuns seus significados próprios e substitui-los por um significado que manifestamente não têm.

De fato, a respeito de algumas questóes filosóficas, quando tratadas sem dogmatismo, um neopirrônico poderia oferecer algumas respostas. Por exemplo, para a questão filosófica da definição da verdade, um neopirrônico poderia propor uma definição da verdade como uma relaçáo entre o que pensamos ou dizemos e o que se passa no mundo. O que o neopirrônico não pode fazer é sustentar doutrinas sobre o que dizemos e pensamos (por exemplo, são representaçôes mentais, têm a forma "S é P"), doutrinas sobre o mundo (são substâncias com determinadas propriedades) e doutrinas sobre como se dá a correspondência (por exemplo, uma doutrina sobre o isomorfismo entre pensamento e realidade). Ele também poderá propor uma definição de conhecimento (de um determinado tipo de conhecimento). Segundo essa definição, $S$ sabe que $\mathrm{p}$ se, e somente se, $\mathrm{S}$ justificadamente veio a acreditar que $\mathrm{p}$ por meio de razóes que estabelecem a verdade de p (Fogelin 2017, p. 56). Ele poderá mesmo esclarecer a noção comum de percepção, exibindo todas as relaçóes embutidas nela, mostrando como, de fato, ela implica não apenas uma relação causal, em que o objeto causa uma percepção em uma pessoa (Strawson 1974), mas também como na percepção de alguma coisa estão envolvidos o pensamento e a ação dessa pessoa (Smith 20I4). É nesse sentido que um neopirrônico pode investigar questóes filosóficas, propor resultados e incorporá-los à sua visão cética do mundo. Convém insistir em que diferentes neopirrônicos poderão chegar a diferentes respostas, por exemplo, um neopirrônico pode ser deflacionista sobre a verdade (Barrio, 200o) ou tentar conciliar um correspondencialismo não dogmático com o deflacionismo (Smith, 2007); um mesmo neopirrônico pode, num determinado momento, defen- 
der o realismo científico, ao passo que posteriormente pode se tornar um instrumentalista. À medida que suas respectivas explicitaçóes e elaboraçóes conflitam, suas respectivas visões céticas diferirão.

O leitor decerto sentirá que o neopirronismo, tal como aqui apresentado e defendido, é muito pouco cético e crítico (Fogelin, 20I7, p. 249). Se se aceita que há conhecimento, temos verdades, vivemos segundo crenças que de fato endossamos, se temos até respostas às questóes filosóficas, o que faltaria para esse neopirrônico ser um dogmático? Penso que essa reação é inevitável por causa do sentido que "ceticismo" tem na filosofia moderna e contemporânea: comumente se pensa que o ceticismo tem somente uma parte negativa ou crítica e que não pode ter uma parte positiva. Ora, essa é uma imagem distorcida do pirronismo antigo e, mesmo, de um ceticismo como o de Hume. Mas procurei mostrar que há uma parte positiva, tanto no que diz respeito a uma vida cética guiada por uma razáo cética, quanto no que diz respeito a uma investigaçáo filosófica positiva, que consiste, em grande parte, embora não somente, na descrição das nossas maneiras usuais de conceber o mundo. Menos importante do que saber se o adjetivo "cética" se aplica a essa filosofia aqui esboçada, é saber se o leitor está ou náo de acordo com o que se disse até agora.

Antes de terminar, cabe tratar de um assunto associado a esse: em que consiste a diferença entre uma crença cética e uma crença dogmática? Quais os limites, se existem, entre uma afirmação cética e uma afirmação dogmática? Tentei explicar essa diferença, ainda que brevemente, mais acima. Mas a ideia de que nem sempre fácil distinguir uma crença cética de uma crença dogmática parece-me fecunda e instigante. Vale a pena pensá-la e ter cuidado aqui. Um neopirrônico poderia levar essa ideia longe demais e sentir-se tentado a dizer que as fronteiras são fluídas e que toda frase poderia ser cética ou dogmática, dependendo da atitude com que é afirmada (Frede, 1998, p. 19; Burnyeat 1998, p. 40).

Náo me parece correto dizer que toda crença pode ser cética ou dogmática, que todo conteúdo, por assim dizer, de uma afirmação pode ser considerado, seja como algo relacionado ao mundo que experimentamos, seja sobre uma suposta realidade absoluta (Perin 20ı0, capítulo 3). A meu ver, inúmeras crenças propostas pelos dogmáticos não são, nem podem ser crenças céticas, dado o que os próprios dogmáticos dizem. Por exemplo, a afirmação de Demócrito, segundo a qual "Só existem os átomos e o vazio" é uma afirmação, cujo conteúdo só pode ser dogmático. O fato de que doutrinas dogmáticas "aparecem" (isto é, se impõem) ao intelecto do dogmático não implica que as afirmações também possam ser entendidas como "fenomênicas". Se Demócrito somente relata o que lhe "aparece", não se segue que a frase "Existem átomos e o vazio" possa se referir ao mundo que experimentamos, porque, por definição, átomos e o vazio são coisas não-evidentes (ádela) (Sexto PH I.I3, I.I6, I.2I4). 
Os próprios dogmáticos insistem em que suas doutrinas transcendem o mundo que experimentamos e falam de algo postulado por eles. Nisso consiste boa parte da especulação dogmática. Não entender isso, na medida em que isso pode ser entendido, é não entender o que os próprios dogmáticos estão fazendo.

É certo, no entanto, que muitas frases podem ser tratadas das duas maneiras: de uma maneira, quando dizem respeito ao mundo; de outra maneira, quando dizem respeito às invenções dos dogmáticos. É possível, portanto, que, em alguns, se não em muitos casos, a diferença se deva a uma atitude diante de uma frase idêntica. Mas talvez seja mais adequado dizer que náo se trata tanto de uma atitude diante de uma frase específica, mas de um uso que se faz dessa frase. Talvez não se perceba a diferença entre uma crença cética e dogmática pela frase que se usa, mas pelo uso que se faz dela. Não é fácil, entretanto, descrever com acuidade esse uso filosófico de modo a captar o sentido exato do uso filosófico (Stroud, 2000, capítulo I).

Além disso, uma crença dogmática costuma ser incorporada numa doutrina abrangente e articulada, fruto de uma rigorosa argumentação e aceita como um veredito depois de longa reflexão. Mesmo assim, nem sempre se logra distinguir uma crença banal e uma crença dogmática, porque as doutrinas filosóficas não se constituem somente de crenças dogmáticas, mas incorporam também muitas crenças que um cético poderia ter. Afinal, toda doutrina dogmática se conforma ao mundo que experimentamos e de alguma maneira explica esse mundo que experimentamos, de forma que uma doutrina dogmática não se resume ao que diz sobre esse mundo que postula, mas também incorpora muita coisa que diz sobre o mundo em que vivemos (PH I.I6). Nesse amálgama extenso e complexo, é difícil, se não impossível separar nitidamente crenças dogmáticas e crenças que poderiam ser aceitas por um neopirrônico.

De outro lado, nem toda crença dogmática é fruto de uma argumentação explícita ou resultado de uma fundamentação ou justificação conscientemente levada a cabo. Muitas crenças dogmáticas se disseminam em nossas visóes de mundo sem que nos apercebamos, seja porque se disseminaram séculos atrás, seja porque não prestamos nelas muita atenção, por serem sutis ou óbvias demais. Ora, o cético pode ser vítima inconsciente de inúmeros dogmas, os quais aceitou quando incorporou uma visão comum do mundo. Pode haver, e certamente há, muitos dogmas subreptícios em nossas visões do mundo, não menos na do neopirrônico. Por exemplo, o neopirrônico pode ter tido uma formação religiosa e, nessa sua formação, vem embutida uma enorme gama de crenças, não somente a de que Deus existe. Ao se tornar cético e deixar de acreditar em Deus (essa é, a meu ver, uma crença que só pode ser dogmática), o neopirrônico pode não se dar conta de muitas outras crenças dogmáticas que gravitam em torno dessa crença em Deus, como valores morais que 
só se sustentam nessa visão religiosa, mas que ainda persistem em seu pensamento, por exemplo a imoralidade do aborto.

Ora, erradicar todos esses dogmatismos sub-reptícios é tarefa árdua; livrar-se de muitas crenças dogmáticas que podem estruturar uma determinada concepçáo do mundo exige esforço e seriedade intelectual. Ao elaborar sua visão cética do mundo, o cético não somente fornece uma descrição de suas crenças, mas também continua a eliminar possíveis crenças dogmáticas difundidas em seu pensamento. A tarefa negativa de criticar dogmas não se dirige somente aos dogmáticos, mas também a si mesmo; e ela não se esgota naquela suspensão do juízo sobre todas as questôes filosóficas, mas é uma tarefa permanente, na verdade infindável. Ao contrário dos dogmatismos, exerce a autocrítica com afinco, sempre examinando se não haveria, em sua própria concepção, dogmas escondidos. Em geral, o dogmático se caracteriza por não questionar ou examinar seus próprios pressupostos, limitando-se a criticar os pressupostos dos demais dogmáticos. É preciso reconhecer, no entanto, que é muito mais fácil identificar os dogmas alheios do que os próprios...

\section{Referências bibliográficas}

Annas, J. (1993). The Morality of Happiness. Oxford: Oxford University Press.

Barnes, J. (1998). “The Beliefs of a Pyrrhonist”. Em: Michael Frede; Myles Burnyeat (eds.) The Original Sceptics: A Controversy. Indianapolis/Cambridge: Hackett.

Barney, R. (20I8). "Sextus Empiricus and Skeptical Inquiry", texto apresentado no II Colóquio Latinoamericano de Estudo Céticos, Natal.

Barrio, E. (2000). "La otra cara del escéptico", in: Luiz Henrique de A. Dutra; Plínio J. Smith (eds.) Ceticismo: perspectivas históricas e filosóficas. Florianópolis: Editora da UFSC.

Bayle, P. (DHC). Dicionário histórico e crítico. Tradução de Plínio Junqueira Smith e Roberta Soromenho Nicolete. São Paulo: Editora da UNESP (em preparação).

Burnyeat, M. (1998) “Can the Sceptic Live His Scepticism?”, in: Michael Frede; Myles Burnyeat (eds.) The Original Sceptics: A Controversy. Indianapolis/Cambridge: Hackett.

Christensen, D.; Lackey, J. (eds.). (2013). The Epistemology of Disagreement: New Essays. Oxford: Oxford University Press.

Elgin, K. (20I0). "Persistent disagreement", in: Richard Feldman; Ted A. Warfield (eds.) Disagreement. Oxford: Oxford University Press.

Fine, G. (2000). "Sceptical Dógmata: Outlines of Pyrrhonism I I3”. Méthexis I3: 8I-IO5.

Fogelin, R. J. (2004). “The Skeptics are Coming! The Skeptics are Coming!”. Em: Walter Sinbott-Armstrong (ed.) Pyrrhonian Skepticism. Oxford: Oxford University Press. 
Fogelin, R. J. (20I6). Andando na corda bamba da razão. Tradução de Plínio Junqueira Smith e Israel Vilas Bôas. São Paulo: Alameda Editorial.

Fogelin, R. J. (20I7). Reflexôes pirrônicas sobre o conhecimento e a justificação. Tradução de Israel Vilas Bôas. Salvador: Editora da UFBA.

Frances, B. (20I4). Disagreement. Cambridge: Polity Press.

Frede, M. (1998). “The Sceptic's Beliefs”, in: Michael Frede; Myles Burnyeat (eds.) The Original Sceptics: A Controversy. Indianapolis/Cambridge: Hackett.

Friedman, J. (2015). "Why Suspend Judging?” Nồs 5I(2): I-25.

Friedman, J. (20I7). "Inquiry and Belief”. Nô̂s, p. I-20 (no prelo).

Hume, D. (1986). An Enquiry concerning the Human Understanding. P. H. Nidditch (ed.). Oxford: Oxford University Press.

Kornblith, H. (2013). "Is Philosophical Knowledge Possible?", in: Diego E. Machuca 9ed.) Disagreement and Skepticism. New York and London: Routledge.

Kuhn, T. (1970). The Structure of Scientific Revolutions, $2^{\text {nd }}$ edition. Chicago: the University of Chicago Press.

Lacey, H. (2008). Valores e atividade científica I. São Paulo: Associação Filosófica Scientiae Studia/Editora 34.

Laudan, L. (1984). Science and Values: the aims of Science and their role in scientific debate. Berkeley/Los Angeles/London: University of California Press.

McDowell, J. (2009). "Conceptual Capacities in Perception”, in: Having the World in View: Essays on Kant, Hegel, and Sellars. Cambridge, Massachusetts/London, England: Harvard University Press.

Morison, B. (20II). “The Logical Structure of the Sceptic's Opposition”, in: Essays in Memory of Michael Frede, James Allen, E. Emilson, W. Mann (eds.). Oxford Studies in Ancient Philosophy 40: 265-95.

Orlando, E. (2007). "Dudas escépticas sobre la filosofia escéptica de la mente". Sképsis I: $\mathrm{I3} 6-\mathrm{I} 42$.

Perin, C. (20IO). The Demands of Reason: an Essay on Pyrrhonian Scepticism. Oxford: Oxford University Press.

Searle, J. (20Io). Consciência e linguagem. Tradução de Plínio Junqueira Smith. São Paulo: wmfmartinsfontes.

Sexto Empírico. (PH). Outlines of Scepticism. Traduçáo de Julia Annas e Jonathan Barnes. Cambridge: Cambridge University Press, 1994.

Smith, P. (M). Against the Ethicists. Tradução, introdução e notas de Richard Bett. Oxford: Clarendon Press, 1997.

Smith, P. (2007). "Verdad, ontologia y deflacionismo", in: Guillermo Hurtado; Oscar Nudler (eds.) El mobiliario del mundo: Ensayos de ontología y metafísica. México: UNAM/IIF. 
Smith, P. (20I4). "A percepção como uma relação: uma análise do conceito comum de percepção". Analytica I8(I): I09-I32.

Smith, P. (20I7). Uma visão cética do mundo: Porchat e a filosofia. São Paulo: Ed. UNESP.

Smith, P. (1985). Skepticism and Naturalism: some varieties. New York: Columbia University Press.

Smith, P. (2002). Análise e metafísica: uma introdução à filosofia. Tradução de Armando Mora de Oliveira. São Paulo: Discurso Editorial.

Smith, P. (2019). Individuos: um ensaio de metafísica descritiva. Tradução de Plínio Junqueira Smith. São Paulo: Ed. UNESP.

Smith, P. (2000). The Quest for Reality: Subjectivism and the Metaphysics of Colour. Oxford: Oxford University Press.

Smith, P. (2018a). "Seeing What is So", in: Seeing, Knowing, Understanding. Oxford: Oxford University Press.

Smith, P. (2018b). "Perceptual Knowledge and the Primacy of Judgment", in: Seeing, Knowing, Understanding. Oxford: Oxford University Press.

Strawson, P. F. (1974). "Causation in Perception”, in: Freedom and Resentment and Other Essays. London and New York: Routledge.

Stroud, B. (1984). The Significance of Philosophical Scepticism. Oxford: Oxford University Press. 